\title{
Elementos sobre a ideia de audiência nos inícios da TV portuguesa
}

\section{Contribution for the idea of audience in early Portuguese TV}

\author{
José Ricardo Carvalheiro*
}

* Universidade da Beira Interior, Portugal

\section{Resumo}

O processo histórico de construção de uma audiência televisiva inclui as representações e os discursos que sobre ela se publicam. Este artigo observa o período inicial da televisão portuguesa, em busca de compreender qual a concepção de audiência que vigorava no salazarismo. Com base na imprensa televisiva da época, cruzamos discursos com origens diversas: nos círculos oficiais e na RTP; nos observadores jornalísticos; nas elites intelectuais; nos próprios telespectadores, que por um momento emergem como público interventivo. Num cenário em que os profissionais dos media tendem a dizer aos espectadores como se deviam comportar e os espectadores tendem a dizer aos produtores como a televisão devia ser, assiste-se a uma competição e a uma negociação entre duas concepções de audiência.

Palavras-chave: Audiência televisiva; Estado Novo; RTP; Debate público; Imprensa

\section{Abstract}

The process of making an audience for television involves also the representations and the discourses published about such audience. Trying to understand which ideas prevailed about the audience during the dictatorship led by Salazar, this paper examines the early period of Portuguese television. It draws on the coeval press dedicated to television, from which it gathered discourses from diverse origins: the official milieu; TV professionals; newspapers journalists; intellectual elites; and members of the public which for a while were quite interventive. Two different conceptions compete about the television audience and a negotiation process takes place within the dictatorial context.

Keywords: Television audience; New State regime; RTP; Public debate; Press

\section{A audiência como ideia}

A constituição de um novo meio de comunicação não implica apenas a criação de práticas profissionais capazes de gerar conteúdos, mas também envolve a produção de uma audiência, e não apenas na sua formação objectiva. Quando a televisão portuguesa começou a emitir, em 1957, estava em causa também a concepção subjectiva da audiência, ou seja, um processo de significação em que um conjunto de discursos e representações procuravam defini-la de um certo modo: onde e como utilizar o novo meio; quem e em que circunstâncias a compunha; o que ela própria esperava, desejava ou exigia.

Sendo certo que não se deve confundir as representações das audiências com a sua experiência histórica real (Bourdon, 2015), um acervo de discursos delas e sobre elas dá acesso a noções, valores e práticas preponderantes numa dada época, inscrevendo-se as próprias representações no processo social que é a experiência de recepção e contribuindo para a forma como as audiências acabam por se fazer a si próprias (Butsch, 2000).

Uma base conceptual fecunda, embora pouco usada, para abordar o processo socio-histórico de adopção de um novo meio de comunicação e a construção da audiência reside nas premissas clássicas do 
interaccionismo simbólico (Blumer, 1969). Estas premissas sustentam que os indivíduos não reagem meramente em relação às coisas, mas agem, sim, em relação aos sentidos que atribuem a essas coisas, 0 que implica encarar o surgimento da televisão não simplesmente como uma nova tecnologia a que as pessoas se adaptaram, mas sim como alvo de um processo interpretativo acerca do que era aquele novo dispositivo e do que significava usá-lo. Por outro lado, os indivíduos vão dando sentido às coisas, não através de meros actos psíquicos, mas sim no seio de interacções sociais onde os significados emergem, são geridos e modificados. É neste sentido que a acção humana constitui um "processo comunicativo em movimento" (Blumer, 1969: XX) e que as próprias audiências podem ser perspectivadas também como uma ideia (Mihelj, 2015), uma ideia construída ou negociada entre jornalistas, actores políticos, produtores dos media e os membros do público.

Em contextos democráticos, as ideias sobre a audiência de televisão tendem a emergir em público sob forma discursiva e, de certo modo, revelam uma relação de forças sociopolíticas num dado momento histórico -, tornando-se claramente, elas próprias, elementos constitutivos das dinâmicas culturais de produção e de apropriação televisiva, como foi proposto por Lynn Spigel acerca do processo de popularização da televisão nos Estados Unidos (Spigel, 1992).

Contextos autoritários, como o Portugal salazarista dos anos 1950 e 60, colocam condições distintas à construção discursiva das audiências, a começar pelo facto de o espaço público ser fortemente capturado para comunicação vertical a partir do Estado ou de actores sociais adjacentes, sendo conhecido o dirigismo do Estado na formação da RTP e o absoluto predomínio das visões oficiais naquilo que ela veiculava (Cádima, 1996; Sousa \& Santos, 2003).

Uma retórica invocadora dos interesses dos cidadãos estava presente, porém, na relação do Estado Novo com os media desde o início da ditadura. Era em nome do público que o regime salazarista se propunha, na Constituição de 1933, "impedir preventiva ou repressivamente a perversão da opinião pública (...) e salvaguardar a integridade moral dos cidadãos". ${ }^{1}$ No caso dos novos meios broadcast, esse desejo de 0 regime formar e moldar uma audiência à sua imagem atravessou as décadas de 1930 e 40, em especial com a experiência radiofónica da Emissora Nacional, onde - sob a égide de António Ferro e, depois, directamente do Secretariado de Propaganda Nacional - se declarava que "as exigências medíocres de certas camadas da população (...) precisam de ser orientadas, ensinadas" e onde se tomava "a pesada responsabilidade da educação cívica, moral e artística do nosso povo". ${ }^{2}$

Actuar em nome do público, mas sem seguir a vontade deste era, portanto, uma marca genética do regime, consentânea com a sua matriz antidemocrática. Nas exemplares palavras de Ferro em 1941, a política do Estado Novo para os meios de comunicação existia, precisamente, "para combater ou converter" esse público com apetites adversos. ${ }^{3}$

Assim, quando se tratou de criar a televisão portuguesa, as necessidades da audiência foram, desde logo, antecipadas pelos documentos oficiais do regime. O decreto-lei de 1955 que definiu a concessão do serviço televisivo estipulou a obrigação de produzir "programas de nível elevado (...) de modo a preencher (...) as necessidades do público". ${ }^{4}$ A redacção da lei mostra uma concepção da televisão prioritariamente como

\footnotetext{
${ }^{1}$ Constituição do Estado Novo, artigo $8^{\circ}$, parágrafo $20^{\circ}$, alínea $2^{\mathrm{a}}$.

2 Discurso de tomada de posse de António Ferro na Emissora Nacional, publicado no semanário Rádio Nacional, $22 / 06 / 1941$, p. 5. António Ferro, influente intelectual salazarista, dirigiu o Secretariado de Propaganda Nacional (mais tarde Secretariado Nacional de Informação, SNI) entre 1933 e 1950, e esteve à frente da própria rádio pública entre 1941 e o final do seu mandato no SNI.

${ }^{3}$ Idem, ibidem, p. 5.

${ }^{4}$ Decreto-lei no 40 341, de 18 de Outubro de 1955, base X, ponto 1. Itálico nosso.
} 
instrumento para incutir na população determinados conteúdos formativos: "os programas deverão ter carácter essencialmente educativo, recreativo, cultural e de informação, dentro dos princípios morais e sociais instituídos pela Constituição". ${ }^{5}$

Note-se que falar em educação do público no contexto salazarista significa sobretudo um desejo de doutrinálo dentro de um apertado crivo ideológico, estético e moral, bem patente naquilo que Ferro definiu como uma "política do espírito", projecto que ambicionava disseminar um sistema de valores por todos os meios e géneros culturais de forma mais ou menos subtil (Ó, 1999; Ribeiro, 2005).

É preciso ter em conta, no entanto, que a introdução de televisores no tecido social português foi demorada, tal como aconteceu em outros países da Europa do sul, nomeadamente em Itália e Espanha, onde a televisão foi um fenómeno inicialmente confinado a algumas regiões (Penati, 2013; Lozano, 2014). No final do primeiro ano de emissões, o território português abrangido pelas transmissões correspondia a $45 \%$ da população e só dez anos mais tarde a cobertura atingiria 95\% (Silva \& Teves, 1971). Mas o ritmo de aquisição de televisores foi ainda muito mais demorado, como a tabela 1 mostra. ${ }^{6}$

Tabela 1

\begin{tabular}{|c|c|c|}
\hline Ano & $\begin{array}{c}\text { Número } \\
\text { de televisores }\end{array}$ & $\begin{array}{c}\text { Televisores por } \\
1000 \text { habitantes }\end{array}$ \\
\hline 1957 & 2518 & 0,3 \\
\hline 1959 & 31268 & 3,5 \\
\hline 1961 & 68174 & 7,6 \\
\hline 1963 & 119282 & 13,4 \\
\hline 1965 & 180093 & 20,3 \\
\hline 1967 & 271025 & 30,4 \\
\hline 1969 & 347399 & 39,1 \\
\hline
\end{tabular}

O número de pessoas com efectivo acesso à televisão durante o salazarismo foi bastante reduzido ou condicionado, com o aparelho televisivo a ser um relativo privilégio e a requerer estratégias de visionamento colectivo no seio das classes populares. ${ }^{7}$

\section{Objectivos}

Tendo em conta a posição oficial do regime e a lenta penetração do televisor na realidade doméstica, este artigo procura pistas que permitam detectar e compreender a eventual existência de vários discursos

\footnotetext{
${ }^{5}$ Ibidem, base $\mathrm{X}$, ponto 2 .

${ }^{6}$ Os dados acerca do número de televisores baseiam-se nas publicações do Instituto Nacional de Estatística, que durante o período analisado foi contabilizando nos volumes anuais das "Estatísticas da Educação" o número de televisores registados no país.

${ }^{7}$ No início dos anos 60, os modelos mais baratos de televisor oscilavam entre os 4 e os 6 mil escudos, a avaliar pela publicidade na imprensa (ver A. Galhardo, 2008). Os ordenados médios mensais na indústria portuguesa oscilavam, em 1962, entre os cerca de 2 mil escudos no sector têxtil e os 6 mil escudos no sector cervejeiro (ver Pintado, 1967).
} 
preconizados em torno da ideia de audiência televisiva na fase inicial da sua formação em Portugal, que tomamos aqui como o período em que a RTP coincidiu com o governo de Salazar (1957-1968). ${ }^{8}$

Na verdade, as ideias acerca da audiência não são simplesmente opiniões. São ideias socialmente situadas, pontos de vista de determinados actores a partir de certos lugares e que, neste caso, conteriam um conjunto de interesses e aspirações relativamente à televisão nas décadas de 1950 e 1960.

A primeira questão que colocamos é se - no seio de um regime oficialmente monolítico e de um sistema mediático controlado e vigiado - a televisão e a constituição da sua audiência terão provocado alguma manifestação de posições diversas que correspondessem a diferentes visões do mundo e a clivagens existentes na sociedade portuguesa. Aspectos como a programação televisiva, em grande medida encarados como pertencendo ao domínio dos gostos e das preferências, prestam-se a uma atitude não necessariamente vista como política e seriam por isso susceptíveis de alguma tolerância da censura sobre o espaço público, podendo por essa via relevarem-se discursos que, em sentido amplo, tenham um fundo realmente sociopolítico.

A segunda questão relaciona-se com a busca de dinâmicas diacrónicas, ou seja, com a hipótese de que a(s) ideia(s) de audiência se possa(m) ter modificado ao longo do período em causa ou de que poderão ter coexistido diversas perspectivas cuja interacção terá eventualmente resultado numa concepção predominante.

Uma das componentes que procuramos apreender é a capacidade, ou não, que a própria audiência teve para participar na ideia que de si mesma se projectava e, por consequência, na representação das suas características, dos efeitos da televisão sobre si e das suas aspirações acerca dela. Neste sentido, interessanos averiguar, afinal, se as audiências iniciais da TV portuguesa puderam em algum momento afirmar-se como públicos, no preciso sentido de se constituírem como grupos dispostos a agir discursivamente sobre um assunto comum que Ihes diz respeito (Dahlgren, 1995).

Por outro lado, não desprezaremos, ao longo do artigo, indicações sobre as efectivas práticas de recepção, mas esse aspecto é lateral à nossa pesquisa e apenas funcionará como elemento de contextualização dos discursos, uma vez que se trata sobretudo de compreender quais eram as concepções, as aspirações ou os receios acerca da audiência televisiva que se estava a formar.

\section{Método}

Uma vez que a construção subjectiva da audiência tende a fazer-se numa negociação entre produtores, espectadores e outros actores sociais - negociação que faz parte da história de um meio de comunicação , esse processo é passível de deixar registos sob a forma de discursos em que se representa, se aconselha, se interpela ou se verbaliza a audiência.

Tais registos devem ser procurados, evidentemente, em fontes coevas, mas é sabido como as referências às audiências são, por regra, esparsas. A imprensa da época e os arquivos dos órgãos de comunicação não costumam conter mais do que ligeiras pistas acerca das audiências no meio dos dados sobre conteúdos, a orgânica dos media ou a actividade dos profissionais. Pesquisadores da área têm frisado o paciente trabalho que é necessário para extrair dados significativos sobre uma audiência do passado, geralmente obtidos pela

\footnotetext{
${ }^{8}$ Quanto à política televisiva, o governo de Marcello Caetano, a partir de 1968, abriu uma época relativamente distinta (Cádima, 1996; Sousa \& Santos, 2003).
} 
acumulação de referências dispersas, intermitentes e marginais numa vasta quantidade de documentos (Bird, 2008; Mihelj \& Bourdon, 2015).

Por outro lado, nem todas as fontes se equivalem e o risco de prevalecerem apenas fontes institucionais e representações emanadas das elites - risco acrescido num regime ditatorial e censório - aconselha a um mapeamento criterioso do material a pesquisar. Neste sentido, inspirámo-nos na proposta de Jérôme Bourdon (2015) para uma tipologia das fontes históricas acerca das audiências, que sistematiza os materiais empíricos segundo três tipos de origens: (i) "fontes de cima", (ii) "fontes laterais" e (iii) "fontes de baixo", consoante se trate de representações e discursos sobre as audiências (i) emanados do poder político ou mediático, (ii) produzidos por testemunhas não pertencentes às elites nem ao meio em causa ou (iii) expressas pelos próprios membros da audiência (Bourdon, 2015, p. 12).

Mas onde encontrar, com alguma probabilidade, esta diversidade de fontes? Por um lado, víamo-nos confrontados com um difícil acesso directo a fontes de baixo, que poderiam obter-se caso existisse um arquivo com a correspondência de telespectadores nos primeiros anos da RTP. ${ }^{9}$ Eleger a imprensa como potencial confluência de fontes diversas, confrontava-nos, por outro lado, com a necessidade de evitar uma excessiva dispersão que era expectável em jornais generalistas, onde a televisão e a sua audiência surgiriam como temas muito esporádicos, senão praticamente ausentes no noticiário quotidiano.

Pelo contrário, a "imprensa televisiva" - conjunto de publicações periódicas cujo principal objecto de atenção era o novo meio de comunicação -, pautava-se por uma óbvia concentração temática e afigurava-se capaz de proporcionar dados relevantes acerca da audiência num universo de dimensões pesquisáveis. O seu cariz público potenciava o acesso àqueles discursos que terão efectivamente participado na construção social da audiência, assim como a sua natureza diacrónica permitia apreender eventuais padrões de repetição, negociação ou mudança.

Entre o lançamento da RTP e o fim do governo de Salazar, identificámos a publicação de quatro órgãos e com eles constituímos um universo empírico que corresponde à totalidade da imprensa televisiva existente na época. ${ }^{10}$ Essas publicações (que não coincidiram todas no tempo) são: a revista semanal Rádio $e$ Televisão ${ }^{11}$; a revista semanal TV - Semanário da RTP12; o quinzenário TV Magazine ${ }^{13}$.

O corpus da pesquisa foi constituído pela totalidade das edições publicadas entre Setembro de 1956 (início das emissões experimentais da RTP) e Dezembro de 1958, numa exploração exaustiva dos dois anos iniciais de televisão em Portugal ${ }^{14}$; e por amostras posteriores que visaram alargar a dimensão diacrónica através

\footnotetext{
${ }^{9}$ Este material, com carácter não público, teria também a vantagem de não ter sido sujeito ao crivo da censura. Mas, segundo os serviços da RTP, a correspondência não foi guardada nos arquivos da estação.

${ }^{10}$ De fora deixámos publicações genericamente dedicadas a "espectáculos", como a revista Plateia, que incluíam textos regulares sobre televisão mas não a tinham como tema principal.

${ }_{11}$ Propriedade da empresa do Jornal do Comércio e das Colónias, surgiu autodesignada como "revista semanal de espectáculos", mas com papel e formato de jornal (tablóide). O preço inicial era $1 \$ 50$. Começou a publicar-se em Setembro de 1956 e existiu durante todo o período considerado.

12 O primeiro número publicou-se em 2 de Maio de 1963, com preço de capa de $3 \$ 50$. Dirigido por Eduardo Freitas da Costa, que se notabilizou na RTP como salazarista indefectível (ver Cádima, 1996). Publicou-se durante todo o restante período do governo de Salazar.

13 Propriedade da firma Aguiar \& Silva. Publicou-se entre Outubro de 1957 e Maio de 1958, dirigido por Vítor Direito. Publicação a cores, com preço de $3 \$ 00$.

${ }^{14} \mathrm{O}$ corpus referente a este período foi exactamente o seguinte: os primeiros 121 números do semanário Rádio e Televisão (de Setembro de 1956 a Dezembro de 1958); os primeiros e únicos 15 números do quinzenário TV Magazine (de Outubro de 1957 a Maio de 1958).
} 
dos anos de 1963 (ano em que surgiu o semanário da RTP) e 1966 (ano em que se deu um aumento notável do número de televisores). ${ }^{15}$

Apesar de ser um único tipo de fonte documental, em termos metodológicos encaramos o conjunto da imprensa televisiva como um acervo composto por uma pluralidade de fontes, onde a natureza diversa dos órgãos e dos conteúdos fornece de facto uma variedade de fontes originais: jornalistas, colaboradores, membros do governo, representantes oficiais da RTP, leitores-telespectadores. No interior da imprensa é necessário, pois, distinguir entre os discursos sobre as audiências feitos pelo regime, a RTP e as vozes que os amplificam, relativamente aos discursos de outros observadores e às intervenções do próprio público.

A proposta de Bourdon, que noutras pesquisas dicotomiza entre fontes documentais "de cima e do lado" e histórias de vida "de baixo" (Brennan, 2016), é por nós adaptada de forma a confrontar actores sociais distintos no interior da imprensa, mantendo como critério uniforme o recurso a fontes coevas. Assim, consideramos como "fontes de cima" as representações da audiência na revista da RTP, bem como as intervenções de actores políticos e membros da estação televisiva nas outras publicações; como "fontes laterais" outras referências à audiência na imprensa televisiva não directamente ligada aos produtores e dirigentes de televisão, nem tutelada directamente pelo Estado; como "fontes de baixo" os discursos do próprio público, nomeadamente a correspondência reproduzida nesses mesmos jornais, bem como as vozes de telespectadores publicadas em reportagens ou entrevistas.

Assim, na abordagem do corpus fizemos uma triagem de todos os materiais que continham referências explícitas ou implícitas à audiência, reunindo um acervo com cerca de 180 peças que inclui editoriais, artigos, textos de opinião, entrevistas, reportagens e cartoons - confirmando-se que, mesmo na imprensa televisiva, o público é aludido numa minoria de textos. A estes junta-se, no entanto, um conjunto muito significativo de cartas de leitores (aproximadamente 200 no conjunto do corpus) que acabou por nos fornecer um manancial de pontos de vista das "fontes de baixo". Neste caso, procurou-se, também, situar socialmente os autores dos textos sempre que havia indicadores para tal (relativos a género, classe, meio urbano/rural). A análise teve em consideração a existência de três categorias textuais fundamentalmente distintas em relação à audiência: os enunciados que a representam, os enunciados que a interpelam e os enunciados que Ihe dão voz. Mas o principal propósito da análise foi mapear os discursos quanto ao seu sentido, o que foi feito de forma indutiva através da identificação de temáticas, recorrência de ideias e surgimento de padrões que permitem apontar a existência de determinadas ideias de audiência.

\section{Uma audiência a educar}

Apesar de a audiência inicial não incluir as grandes "massas", o discurso público predominante ao longo dos dois primeiros anos recorre com frequência a um tom paternalista em que os responsáveis da estação ou figuras próximas exprimem no semanário Rádio e Televisão a ideia de uma audiência que necessita de ser educada e doutrinada. O "programa" foi, aliás, traçado logo no primeiro número deste semanário, onde se alertava para "os perigos inerentes a uma programação mal encaminhada (...) que em todo o mundo vem

\footnotetext{
${ }^{15}$ Relativamente a 1963, a pesquisa examinou seis meses de cada uma das duas publicações então existentes: de Maio (mês do lançamento) a Outubro no caso do semanário TV, da RTP; de Janeiro a Junho no caso de Rádio e Televisão. A pesquisa foi complementada com uma amostra de 1966, apenas para o semanário da RTP (meses de Janeiro a Março).
} 
criando uma «standardização» da cultura que tende a diluir, desfazer e destruir uma escola de valores para a substituir por um tipo único de entretenimento pseudo cultural que leva ao nivelamento ético e estético". ${ }^{16}$ Esta ideia, muito saliente, de orientação 'cultural' mesclada com voluntarismo nacionalista, ecoava a posição oficial da própria RTP, cujo programa politicamente determinado se anunciava na mesma altura através da primeira brochura distribuída ao público: "A Radiotelevisão Portuguesa foi criada em obediência a um imperativo de progresso e valorização nacional. (...) Trata-se (...) de aumentar a cultura dos homens, de educar distraindo, de satisfazer as necessidades espirituais de toda a ordem, para toda a gente (...). Ao serviço da Arte, da Ciência, da Técnica, da Cultura, a televisão é (...) um instrumento de educação."17

Este tipo de discurso vai desdobrar-se a partir "de cima" não apenas no sentido de emanar do poder político ou da RTP, mas também por vir de um topo "social", uma vez que ele é apanágio das elites intelectuais de forma ampla, incluindo as menos alinhadas com o salazarismo e que não pertencem ao establishment político ou televisivo. ${ }^{18}$ A concepção, por parte das elites, de que a audiência precisa de ser educada surge, nos círculos tradicionalistas e nacionalistas do regime, em ligação com os valores conservadores e a promoção ideológica de uma 'cultura portuguesa'; mas noutros sectores intelectuais parece alimentar-se da aversão à 'vulgaridade' do entretenimento popular ligeiro e a uma deterioração vislumbrada na cultura para as massas. ${ }^{19}$

O discurso que insistia na "cultura" e na educação do público continha, em si mesmo, aquele contraponto acerca da concepção de audiência com "apetites adversos" que já António Ferro prometera combater, nos anos 40, através da rádio. No caso da televisão, a ideia de audiência alvo-a-instruir voltava a fazer sentido, não simplesmente por se tratar de uma audiência inculta, mas (e sobretudo) por nela se reconhecer apetências de outra índole, nomeadamente para a fruição de distracção ligeira. Tal sensação ter-se-á intensificado no decorrer dos primeiros dois anos de emissões, como sugere o seguinte excerto: "Não pomos dúvidas que existem muitos outros espectáculos de agrado geral. Cremos porém que à televisão não compete apenas distrair o público, levando até junto dele «programas para rir» ou para agradar à «rapaziada da leitaria», que a sua missão ultrapassa em muito o medíocre cartaz revisteiro; a ela compete difundir a cultura, educar, orientar e aperfeiçoar o gosto e os interesses da grande massa." 20

\section{Uma audiência seduzida}

Na fase inicial, uma outra forma de a imprensa televisiva representar a audiência é como beneficiária de extraordinários progressos técnicos, de um maravilhamento que apela à imaginação das pessoas comuns.

\footnotetext{
${ }_{16}$ Artigo que, na altura das emissões experimentais, antevê os destinatários da televisão na mesma linha das preocupações que já existiam nas elites do regime em relação à audiência da rádio, em consonância com a concepção desenvolvida por António Ferro. O texto é, assinado pela Comissão Organizadora de um anunciado 'Centro de Estudos da Rádio e Televisão', identificada como um conjunto de intelectuais, artistas, produtores e autores. (Rádio e Televisão, n०1, 8/9/1956, p.3)

${ }_{17}$ Brochura distribuída pela RTP no arranque das emissões experimentais, em Setembro de 1956, citada em Silva e Teves (1971), p. 127.

${ }_{18} \mathrm{Na}$ imprensa televisiva, a defesa da promoção cultural do público surge com frequência pela voz de intelectuais, independentemente da sua maior ou menor sintonia com o regime.

${ }^{19}$ É o caso da jornalista Etelvina Lopes de Almeida, que em 1948 fora afastada da Emissora Nacional por defender a criação de partidos políticos e eleições livres: "Sendo uma miniatura do cinema e uma reprodução mínima do teatro, [a televisão] não me satisfaz." (TV Magazine, no 5, 15/12/1957, p. 9).

${ }^{20}$ Rádio e Televisão (doravante RT), no 116, 22/11/58, p. 2.
} 
Sobretudo a audiência popular é mostrada como um alvo de poderosa sedução, como nas emissões experimentais, em que "programas inteiros de televisão são admirados pelos feirantes que boquiabertos se espantam de ver nos pequenos écrans figuras conhecidas, tornadas anãs, e que fazem as delícias dos seus olhos esbugalhados". 21

Seja pela fascinação e o maravilhamento técnico ou seja pela oferta de diversão e espectáculo, a audiência que os discursos interpelam e propõem desde o início é uma audiência imaginada como doméstica e familiar que é incapaz de resistir aos encantos do novo meio. Em vésperas de começarem as emissões regulares, Rádio e Televisão dirige-se ao leitor nos seguintes termos: "Já comprou o seu receptor de televisão? (...) escusa de dizer-nos que não o fará (...) porque o senhor disse o mesmo quando a rádio apareceu entre nós (...) a televisão é inevitável. Basta que um dia o seu vizinho do lado, numa tarde de chuva e em pantufas, a assistir à final da taça de Inglaterra em futebol (...) para que o senhor corra a comprar um receptor".22 Este discurso, que parece emanar sobretudo de fontes "laterais" (os jornalistas da imprensa), introduz desde o início uma boa dose de ambivalência na ideia de audiência. Verifica-se que esta nem sempre segue a versão oficial de um público a quem a televisão iria instruir e enquadrar no gosto cultural preconizado pelo regime e pelas elites. Aliás, um modo recorrente de a imprensa interpelar a audiência nos primeiros anos é classificar a televisão como um novo "espectáculo", colocando-a assim, implicitamente, mais no terreno do lazer e do consumo do que no da educação e da formação cultural. ${ }^{23}$ Imagina-se o 'chefe de família' seduzido pelo espectáculo popular e pelo conforto doméstico: "Só quem [não] viu em sua casa, no seu «cantinho de repouso» calmamente instalado, a «nossa» TV, não sabe nem calcula o que está a perder". ${ }^{24}$

\section{A ambivalência das fontes "laterais"}

O carácter da imprensa televisiva enquanto "fonte de fontes" merece um breve enquadramento. Com excepção da revista da RTP (que só nascerá em 1963), esta imprensa era relativamente ambivalente na sua abordagem jornalística: não deixava de ser obviamente próxima da estação televisiva nem se furtava à vigilância política, mas também não funcionava como mera correia de transmissão ao serviço de produtores e dirigentes televisivos.

Além disso, no caso do semanário Rádio e Televisão (de particular importância por ser a única publicação perene em todo o período em causa) é possível perceber claras oscilações que têm correlação com mudanças de director e que se traduzem em maior ou menor abertura a vozes diversas. Em alguns períodos predomina o tom oficial e o discurso consonante com a RTP, nomeadamente nos primeiros sete meses (a partir de Setembro de 1956), em que a revista é dirigida por Diniz Bordallo-Pinheiro, que foi membro da Câmara Corporativa do Estado Novo; assim como no início de 1963, altura em que o semanário vinha sendo dirigido, havia quatro anos, por Caetano de Carvalho, que antes fora conselheiro cultural da RTP e era claramente um "homem do sistema".

Mas há uma fase em que é evidente a vontade de independência, especialmente patente na publicação de abundante correspondência de leitores críticos - abrindo amplo espaço para "fontes de baixo" -, bem como de textos de colaboradores que são pouco abonatórios para a estação televisiva. Isso acontece num período

\footnotetext{
${ }^{21}$ RT, no 2, 15/09/1956, p. 16.

${ }^{22}$ RT, no 24, 16/02/1957, p. 9

${ }^{23}$ É o caso, também, da revista TV Magazine, que no primeiro número se dirige aos leitores-telespectadores enquanto público que se insere "no quadro dos espectáculos em Portugal" (15/10/1957, p. 3).

${ }^{24} \mathrm{RT}, \mathrm{n}^{\circ} 69,28 / 12 / 1957$, p. 10.
} 
que começa em Abril de 1957, quando a direç̧ão da revista é entregue a Fausto Lopo de Carvalho, escritor e figura mais tarde identificada com círculos da oposição ao regime.

Isto confirma que a distinção entre "fontes de cima" e "fontes laterais" na imprensa não é completamente linear e que jornalistas e colaboradores da imprensa televisiva não terão tido necessariamente o estatuto de elites mediáticas no âmbito da televisão, podendo ter assumido parcialmente um papel de actores não colados à produção televisiva e à sua direcção política, embora em certas circunstâncias também pudessem actuar como difusores do discurso oficial.

\section{Um público surpreendente}

Neste contexto, a criação de um espaço para cartas de leitores no semanário Rádio e Televisão proporcionanos informação valiosa de "fontes de baixo", quer acerca de algumas características da audiência em formação, quer sobretudo das concepções que a audiência tinha de si própria e do seu lugar face ao novo dispositivo comunicacional.

O espaço "Tenha Opinião" foi criado cinco semanas após o início das emissões regulares, coincidindo com a posse de Fausto Lopo de Carvalho como director do semanário, mas vai ser intermitente ao longo de 1957. Em Janeiro seguinte, porém, a rubrica é rebaptizada com a designação "Seja um crítico", o seu espaço aumenta e, ao longo de 1958, a revista irá publicar ao todo 183 cartas de telespectadores, quase exclusivamente dedicadas a questões televisivas. ${ }^{25}$ As páginas que a revista dedica à correspondência funcionam frequentemente como uma autêntica tribuna dos telespectadores, instala-se o diálogo e da audiência televisiva vai emanar um público interveniente.

Cabe notar como a revista dá um carácter interpelante à designação das rubricas, indicador da disposição, e talvez da necessidade, de estimular a emergência de um público activo. Esta atitude, juntamente com o leque de abordagens que vão surgindo nas páginas da revista reforça a ideia de que ela funcionava, nesta fase, como uma relação de forças entre uma série de actores com interesse em influenciar o rumo da televisão e sugere que tentou juntar a essas forças a própria audiência (numa estratégia, possivelmente, de afirmar a próprio semanário).

O tema que enquadrou as primeiras vozes do público foi o da tutela moral e educativa por parte das entidades oficiais, com a proibição de a televisão exibir programas classificados para maiores de 12 anos. Na primeira carta, nove espectadores de Lisboa, incluindo um "doutor" e um "engenheiro", reivindicam que o público seja tratado como adulto: "um aparelho é suficientemente caro para que uma pessoa se limite a ver espectáculos infantis". ${ }^{26}$ Outro leitor, adoptando a óptica de uma audiência doméstica, argumenta que "a televisão não é espectáculo público. Pode parecê-lo, mas não é difícil ver que se trata de um espectáculo caseiro, privado! E, em nossas casas, mal dos pais que não sabem educar os filhos". ${ }^{27}$ Uma "mãe de família" defende que "num lar de um certo nível moral e mental deve haver sempre uma pessoa, pai ou mãe, quando

\footnotetext{
${ }^{25}$ Em média, são publicadas mais de três cartas por cada uma das 52 edições desse ano e trata-se, maioritariamente, de textos com alguma dimensão, ocupando a rubrica frequentemente duas páginas completas do semanário.

${ }^{26}$ RT, no 36, 18/5/1957, p. 9.

${ }^{27}$ RT, no $37,18 / 5 / 1957$, p. 9.
} 
não ambos, que sabe e pode exercer a sua autoridade" e insurge-se contra "esta intromissão da lei nas nossas casas". 28

Outra faceta da audiência se manifestou rapidamente nas cartas: os telespectadores afirmavam-se como público crítico da programação, com opiniões para todos os gostos e propensão para os discutir acerbamente. Esta audiência não se mostrava humilde e reconhecida por haver televisão em Portugal, revelando-se antes reivindicativa, incluindo acerca do direito de cada um exprimir os seus pontos de vista: "Tenha-se em conta o respeito que como cidadãos livres de um país livre como Portugal devem pela opinião dos outros. Não gosta de bola, outros poderá haver que não gostem de outros programas (...) de contrário, seremos egoístas e queremos só do que gostamos". ${ }^{29}$ Dentro do quadro ditatorial, a televisão tornava-se um tema sobre o qual alguma discussão era tolerada em público.

A introdução deste espaço na revista veio mostrar claramente a ausência de um consenso sobre a forma como a audiência se via e se dava a ver, as suas 'necessidades' e aspirações. Entre os colunistas mais sintonizados com a RTP, os ecos de insatisfação ensombram os de entusiasmo e passa-se a representar o público também como impaciente, ou mesmo como impertinente: "Diz-se por toda a parte, especialmente por aqueles que ainda não têm receptor, que a TV não presta, que os receptores estão caros, que as lâmpadas se fundem muito, que os programas são ordinários (...) é fácil pensar assim quando se está de fora e se presta pouca atenção". 30

\section{Representações da recepção colectiva}

A audiência popular ia, entretanto, ganhando os seus próprios contornos. Oito meses depois de terem começado as emissões regulares da RTP, a revista TV Magazine traça o seguinte retrato da audiência lisboeta numa reportagem intitulada "Telespectadores aos milhares - Por toda a cidade de lés-a-lés a televisão ganha numeroso público": "Em todos os lugares onde se encontra um tele-receptor ligado, vamos encontrar também centenas de pessoas (...) Gente de todas as condições sociais procura a maneira de assistir aos programas, quer em cafés mais ou menos confortáveis, quer nas ruas contra as montras dos revendedores". ${ }^{31}$

Se a televisão havia sido apresentada, em primeiro lugar, como veículo "do conforto e distraç̧ão que nos pode proporcionar em nossas casas", 32 a verdade é que a ideia dominante de recepção televisiva como acto doméstico se via confrontada com as práticas reais de outras audiências em formação. O que prova que também em Portugal desde cedo coexistiram "várias culturas de visionamento" (Penati, 2013, p. XII), estendendo-se o consumo televisivo paralelamente como doméstico e como público, como familiar e como colectivo, numa cartografia de práticas em que se articulavam vários factores, nomeadamente a classe social e o eixo urbano-rural (assim como o género, que deixamos de fora desta análise).

Neste processo, as cartas dos leitores vêm revelar que a emergência de reivindicações por parte da audiência não é exclusiva das classes altas e urbanas, desdobrando-se pelo público popular e mesmo pelo público rural que também desponta.

\footnotetext{
${ }^{28}$ RT, no 38, 25/5/1957, p. 10.

${ }^{29} \mathrm{RT}, \mathrm{n}^{\circ} 40,8 / 6 / 1957$, p.4.

${ }^{30} \mathrm{RT}, \mathrm{n}^{\circ} 69,28 / 12 / 1957$, p. 10

${ }^{31}$ TV Magazine, no 3, 15/11/1957, p. 10.

${ }^{32}$ RT, n0 9, 3/11/1956, p. 16.
} 
Em meados de 1957, a Rádio e Televisão faz eco de um leitor de Montemor-o-Novo que se queixa de existirem, espalhados pelas localidades portuguesas, "dezenas de aparelhos de televisão fechados nas salas dos seus possuidores, sem que o grande público possa assistir, às sextas-feiras, à emissão do concurso Veja se Adivinha", rubrica através da qual a RTP oferecia televisores. "Quem comprou um aparelho não é obrigado a abrir as portas da sala a toda a gente da sua terra", respondia a revista, que propunha que se instalasse "um tele-receptor para assistência colectiva" numa das associações da localidade e se criar o "primeiro teleclube português!" 33 Passado um mês, o jornal mostrava fotos do primeiro tele-clube, fundado pelo prior da paróquia de Benfica, em Lisboa, e considerava "as possibilidades desta iniciativa se alargar a todo o país para benefício da população menos favorecida por distracções e espectáculos dignos". ${ }^{34}$ Apesar de "fonte lateral", a imprensa televisiva é um actor interessado na expansão da audiência e na ampliação do fenómeno televisivo em Portugal, razões da sua própria existência. O semanário encara, por isso, a audiência popular pelo ângulo da sua formação, propondo a captação desses espectadores com "distracções e espectáculos" (e não pela educação cultural) e a organização de formas de recepção colectiva capazes de pôr em prática um visionamento alargado e regular (que não deixam de ser, também, formas de enquadramento consonantes com o corporativismo do Estado Novo).

À medida que o número de televisores foi crescendo, as formas de recepção colectiva ter-se-ão desdobrado em múltiplas variantes, com destaque para os estabelecimentos comerciais e as sessões caseiras que congregavam vizinhos e conhecidos. A certa altura, um leitor lisboeta pedia medidas para se travar 0 "comércio ilícito que muitas pessoas exercem em suas casas (...) dando diariamente sessões de televisão e cobrando pelas mesmas um determinado $\mathrm{X}$ escudos por presença". ${ }^{35}$

\section{Direito à televisão}

Se muitos discursos sobre a audiência popular continuaram a ser atravessados pela tensão entre a ideia de instrução e a ideia de diversão, os discursos "de baixo" tendiam, por sua vez, a reivindicar a televisão como algo prosaico, mas importante.

Um espectador do Ribatejo rural defendia a televisão, espécie de bálsamo numa vida ingrata, como um direito que doravante já não podia ser sonegado: "Pela união de todos construiu-se um salão para o qual cada um contribuiu, conforme as suas posses, com trabalho, materiais ou dinheiro, e comprou-se um grande aparelho de $61 \mathrm{~cm}$ de écran. (...) É inútil tentar descrever o entusiasmo que a televisão tem suscitado em quem não podia ter outra distracção. Ele é realmente indescritível. (...) Em face disto, sr. Director, contrariar a televisão em Portugal é querer negar à maioria dos portugueses uma distracção instrutiva que até agora a sua menor sorte lhes tem negado." 36

Se é surpreendente verificar que, num país 'amordaçado', a televisão se tornou num tópico de aceso debate com o contributo do público, ainda mais inesperada é a rapidez como entre a audiência se formou a ideia de um púbico com direitos. Esta concepção está presente no público popular, urbano ou rural, à medida que ele emerge, e tanto abrange o acesso à televisão como o tipo de programas.

\footnotetext{
${ }^{33} \mathrm{RT}$, no 48, 3/8/1957, p. 3.

${ }^{34}$ RT, no $61,2 / 11 / 1957$, p. 2

${ }^{35}$ RT, no 101, 9/08/1958, p. 6.

${ }^{36} \mathrm{RT}^{\circ}$ n $^{83}$, 5/4/1958, pp. 6-7.
} 
Num dos vários testemunhos de reuniões domésticas para se ver televisão, um leitor de Cascais apresentase humildemente "com o exame da $4^{a}$ classe" e reporta a tensão que existe entre uma audiência cultivada e uma audiência que se quer divertir: "Todas as noites se juntam em minha casa 10 a 15 pessoas dos dois sexos a ver as emissões, incluindo família e vizinhos. (...) Seria impossível agradar a todas as camadas de espectadores e isso deriva do desnível cultural dos mesmos. A RTP foi criada para os portugueses, mas talvez $70 \%$ dos mesmos não teve formação para compreender esses programas de cultura literária e musical e acabam, uns após outros, por dizerem boa noite, até amanhã, está-me a dar o sono". ${ }^{37}$

De facto, a carta deste espectador 'humilde' não se destina meramente a defender um certo tipo de programação - vários espectadores de classes altas também defendem conteúdos ligeiros -, mas a invocar a desigualdade sociocultural da audiência para afirmar que a RTP deve "encher as emissões" com programas populares e, "quanto à hora em que devem ser transmitidos", apresenta novas razões classistas: "julgo ser melhor a seguir ao noticiário (...) e deixar os mais pesados para o fim, visto que a maioria é tudo gente que trabalha e tem que se levantar no dia seguinte, muitos às 6 horas da manhã (...) Ao passo que os telespectadores mais cultos têm outro horário de entrada no serviço e outros há que nem têm empregos". ${ }^{38}$ Não existindo uma sobreposição entre classe social e concepção de audiência, a verdade é que o aceso debate entre a ideia de público a cultivar e público a entreter, remete frequentemente, de forma explícita ou implícita, para a condição socioeconómica e o status social. Enquanto, os que defendem uma audiência 'bem-disposta' argumentam contra a exclusão popular, já os defensores da cultivação usam estratégias discursivas de desqualificação dos opositores, sugerindo o baixo nível dos seus gostos.

É o que se passa no seguinte diálogo. Uma leitora reivindica a inclusão dos não 'intelectuais' na audiência: "Comprei um aparelho de televisão na esperança de passar umas noites agradáveis com a família e amigas. O que encontro?! (...) Não há só 'intelectuais' no nosso país! Coisas simples, alegres, divertidas. É tão bom rir. Nos cafés? É tudo a falar e a dizer o que eu aqui estou escrevendo". ${ }^{39}$

Na semana seguinte, um espectador vem defender o público 'cultural', desqualificando a ideia de 'diversão' da leitora anterior: "Ora, sendo a televisão um meio cultural para aumentar o nível de um povo, os programas culturais ou 'intelectuais', como queira, seriam dados, no seu parecer... a rir! (...) Deixe os 'intelectuais', compre um 'divertido' livro duma colecção azul ou cor-de-rosa, sente-se confortavelmente num sofá, leia o livro se desejar... e não abra o aparelho." 40

\section{Democracia do público}

É interessante que o debate em torno de uma programação educativa ou da adopção de conteúdos mais ligeiros e populares, dilema herdado da «política do espírito» de António Ferro, já não se resuma a uma discussão entre diferentes sensibilidades do regime e dos media, mas seja tomado em mãos pelo próprio público. E mais: a contundente troca pública de argumentos entre espectadores já não se limita a desacordos com base no gosto; em várias ocasiões a questão é funda, pondo em confronto distintas condições sociais, públicos diferentes que disputam entre si o poder de dar uma determinada feição à audiência imaginada pela RTP.

\footnotetext{
${ }^{37}$ RT no 89, 17/5/1958, p. 6.

${ }^{38}$ Ibidem.

${ }^{39}$ RT, no 73, 25/01/1958, p. 6.

${ }^{40} \mathrm{RT}$, no $74,1 / 02 / 1958$, pp. 4-5.
} 
Um leitor do Porto reage à proposta de um espectador lisboeta para mudança de horários, apontando os privilégios de uma minoria: "Eu, além de não ter automóvel, também não tenho aparelho de televisão, o que aliás sucede a 999 de cada mil habitantes desta Invicta Cidade, denominada Metrópole do Trabalho (...) nem o meu ordenado me permite que utilize táxi (...) Como o invejo! (...) sou obrigado a deslocar-me com o único motor de que disponho, as pernas, até casa de uma pessoa de família (...) que possui o «quase» imprescindível aparelho (...). Confiando que [sobre a mudança de horário] V. não permitiria esta ofensa à pobreza, privando-nos deste prazer - um dos poucos acessíveis." 41

O leitor lisboeta contra-ataca com argumentos meritocráticos aplicados à fruição televisiva: "Nunca me passou pela cabeça ofender as gentes [do Porto], especialmente as classes mais pobres, que não possuem meios para comprar um aparelho de TV. Eu já fui operário e sou filho de operários, e se hoje possuo um curso superior, que me permite exercer uma profissão liberal (...) não esqueço que tirei esse curso através de 12 anos de sacrifícios, estudando de dia e trabalhando de noite, talvez em horas a que o meu contraditor dormia sossegadamente. Portanto, se possuo um carro e aparelho de TV, o que parece arreliar o sr. (...), não recebi benesses de ninguém para o efeito". ${ }^{42}$

Este tipo de discussões evidencia como o público televisivo disputava a construção de uma imagem de si próprio e como em torno da televisão se podia lutar por questões de acesso ao lazer, ao consumo e à cultura, pelo mérito individual ou contra a desigualdade social, e pela definição de qual devia ser a audiência destinatária da programação. Algumas cartas contêm proposições claramente políticas: "Pena é que a RTP não opte, mais vezes, por programas leves e alegres, pois são esses, incontestavelmente, os que mais agradam. A TV não é, evidentemente, um espectáculo para classes privilegiadas" [itálico no original]. ${ }^{43}$

Este discurso democratizador dirige-se a um duplo alvo: por um lado, os 'intelectuais' e as 'classes privilegiadas'; por outro, a liderança da RTP e os seus directores de programas. A criatividade popular chega a oferecer a estes últimos alguns versos satíricos: "Lisboa à noite - que enfado/Por que não cortam o Fado/O Café e os Pintores?/Toiradas... que estucha/O Miradoiro outra bucha/Que só interessa aos doutores. (...) Quem sabe, não sabe nada/Por isso nos desagrada/Tanta falta de ciência;/A TêVê é um canudo,/Da TêVê quem sabe tudo/Somos nós... e não Vocência...". ${ }^{44}$ Subjacente a este discurso está nada menos do que a ideia de um público soberano e uma democracia dos espectadores acima dos directores da televisão. Volta a ser surpreendente como, em torno da televisão e do seu carácter popularizante, pudesse brotar tal ideia radical no seio do venerando Portugal salazarista.

O que é um facto é que existiu, pelo menos, um arremedo de democracia discursiva durante um ano nas páginas da revista Rádio e Televisão, até a discussão se rarefazer no final de 1958. A partir dessa altura, as páginas dos leitores escassearam no jornal, passando a privilegiar-se os enfoques jornalísticos sobre os bastidores da televisão onde se veicula, essencialmente, pontos de vista de profissionais e dirigentes da RTP.

\footnotetext{
${ }^{41}$ RT no 97, 12/7/1958, p. 6.

${ }^{42}$ RT no 99, 26/7/1958, p. 6.

${ }^{43}$ RT no 73, 25/1/1958, p. 14.

${ }^{44}$ RT no $98,16 / 7 / 1958$, p. 6.
} 


\section{O discurso da RTP rumo à audiência média}

As esperanças educativas ou democratizadoras caracterizaram a história inicial de sucessivos meios de comunicação e, no caso da televisão, as disputas entre incrementar a formação cultural ou privilegiar o entretenimento de massas ocorreram mesmo em países pautados pela hegemonia do mercado no sistema de media, como os Estados Unidos. Também aí, a imprensa de prestígio deplorou a forma como se defraudou a expectativa de a televisão tornar a ('alta') cultura mais acessível às massas. Ao mesmo tempo, as preferências populares e o argumento democrático da maioria eram usados pelas estações no sentido populista de legitimar como "interesse público" o entretenimento mais apto a captar audiências para os patrocínios comerciais (Welch, 1999).

Portugal tinha uma situação sociopolítica particular e a relação de forças em torno da televisão não era dominada por interesses comerciais. ${ }^{45}$ Nesse contexto, os discursos acerca da cultivação da audiência resistiram durante bastante tempo. Mas, após dois anos de emissões, a forma como alguns jornalistas explicavam o cariz da televisão portuguesa era um sinal de erosão da ideia de audiência a cultivar: "A TV conta histórias e anedotas sem exigir que se saiba ler. (...) A impressionante desproporção entre letrados e iletrados está na base da vitória popular da TV em Portugal" ${ }^{46}$

Numa carta contra mudanças de horário de programas culturais, a Rádio e Televisão hesitava entre ver uma prova de "que ainda há público ou que, finalmente há público capaz de discernir a diferença" [itálico nosso]. ${ }^{47}$ Adeptos da cultivação enfrentavam, pois, este dilema de saber se a insistência da RTP na 'cultura' começava por fim a ter efeitos na audiência ou se, pelo contrário, o público culto era um resquício de algo que a televisão tendia a destruir.

A inexistência de um periódico da RTP antes de 1963 não nos permite saber de forma sistemática qual a sua ideia de público na fase mais inicial, mas é possível indagá-lo quando é lançado o semanário $T V$, órgão oficial da estação, numa altura em que o país superara os 100 mil televisores.

O discurso mais presente na revista da RTP é, nesse momento, um reiterar da heterogeneidade da audiência e dos gostos, que constitui também um discurso de construção da audiência média. Repare-se num dos primeiros editoriais: "Os programas correntes de televisão, posto que devam sempre visar a elevação cultural dos espectadores, às vezes muito difícil de atingir em certas rubricas de agrado geral mesmo nos países com índices de cultura mais elevados, têm finalidade essencialmente recreativa ou informativa". ${ }^{48}$ Instalase uma ambivalência entre o pendor formativo, mantido como proclamação da política televisiva do regime, e o argumento de que a televisão existe para satisfazer os interesses dos espectadores.

A heterogeneidade do público e a dificuldade de um meio de massas corresponder às várias correntes passam a ser as tónicas na forma como, no caso da RTP, o discurso "de cima" representa a audiência. Essa concepção pode ser encontrada de forma mais enfática com o decorrer dos anos. Nas edições de 1966 podemos encontrar assunções claras da audiência como população a captar através de uma oferta mediana: "A televisão é dirigida a todas as espécies de público e deve compreender os denominadores comuns do

\footnotetext{
${ }^{45}$ Além da estação de televisão não ter concorrência e ser tutelada por um estado ditatorial, a 'indústria' televisiva também demorou a desenvolver-se por outros factores, entre os quais o baixo poder de compra, de cujo efeito se pode ter uma ideia comparando o ritmo de aquisição de televisores com o dos Estados Unidos. Após quatro anos de emissões regulares, existia um televisor por cada 7 norte-americanos (1952), mas apenas um por cada 130 portugueses (1961). A cobertura incompleta do território e a má recepção em muitas zonas também terão contribuído para uma lenta disseminação da televisão.

${ }^{46}$ RT, 11/10/1958, p. 15.

${ }^{47} \mathrm{RT}$, no $116,22 / 11 / 1958, \mathrm{p} .2$.

48 TV/RTP, no 3, 16/5/1963, p. 5.
} 
interesse das grandes massas. (...) A estrutura total da programação deve ser concebida para alcançar a maior audiência possível. (...) Os motivos de atracção dos programas não devem ser excessivamente selectivos ou especializados". 49

Uma análise à programação efectiva da RTP (tabela 2) mostra uma tendência para a redução do tempo dedicado a conteúdos "culturais" e um crescimento de conteúdos ligeiros importados, sob forma de séries e filmes. ${ }^{50}$

Tabela 2

\begin{tabular}{|c|c|c|c|c|}
\hline \multicolumn{5}{|c|}{ Percentagem do tempo de emissão } \\
\hline Tipo de programas & 1957 & 1958 & 1963 & 1966 \\
\hline Cultivação & $24 \%$ & $22 \%$ & $7 \%$ & $9 \%$ \\
\hline Entretenimento & $17 \%$ & $16 \%$ & $12 \%$ & $10 \%$ \\
\hline Informação & $14 \%$ & $17 \%$ & $17 \%$ & $15 \%$ \\
\hline Desporto & $4 \%$ & $9 \%$ & $12 \%$ & $6 \%$ \\
\hline Séries e filmes & $6 \%$ & $7 \%$ & $21 \%$ & $16 \%$ \\
\hline
\end{tabular}

A certa altura, a revista da RTP faz mesmo uma curiosa inversão do discurso oficial e, em vez de apelar à audiência vulgar para se cultivar, passa a apelar aos cultivados para tolerarem a diversão ligeira: "Meu caro telespectador: imagine a indigestão que não teria vendo nos écrans só obras-primas interpretadas pelos melhores. A TV tem de ser espectáculo para a multidão dos telespectadores. Não pode contentar apenas uma reduzidíssima elite. Não é só, portanto, a TV que é preciso melhorar, mas também os indivíduos que a vêem e a criticam". ${ }^{51}$

Contudo, as páginas criadas pela RTP para o "diálogo" com o público nunca chegam a ser espaços de debate. Por um lado, esse espaço torna-se predominantemente uma transcrição de excertos da imprensa seguidos de comentários em que a revista responde às apreciações negativas, frequentemente com acinte. Logo um mês após o lançamento, o semanário oficial cria uma outra rubrica a que chama «Legítima defesa», onde começa por deslegitimar os críticos, cuja prosa "mal-intencionada e leviana (...) desconhece por completo (...) a própria essência da matéria".52 Um par de meses depois, o editorial dirigia-se aos telespectadores do seguinte modo: "Não se deve censurar o que se ignora. Para mais amplo conhecimento dos seus serviços e informações dos seus programas, existe na RTP o serviço de Relações Públicas (...) Pomo-lo à vossa disposição". ${ }^{53}$ A RTP não estava, obviamente, interessada num debate público e crítico com os telespectadores. Preferia dissuadi-lo ou encaminhar as questões da audiência para o interior silencioso da organização.

${ }^{49}$ TV/RTP, 24/2/1966, pp. 28-29.

${ }^{50}$ Análise própria a partir de amostras dos quatro anos considerados. A categoria definida como de cultivação agrega os programas de "cultura erudita" (literatura, artes plásticas, música e dança clássicas, teatro dramático) e os de divulgação científica ou histórica.

${ }^{51}$ TV/RTP, no 141, 6/1/1966, p. 14.

52 TV/RTP, no 5, 30/5/1963, p. 10.

53 TV/RTP, no 24, 10/10/1963, p. 5. 


\section{Conclusões}

Apesar do regime ditatorial, da doutrina dirigista e dos entraves ao debate, a construção inicial de uma audiência televisiva em Portugal não terá deixado de ser um processo influenciado pela interacção entre a RTP e o público, bem como entre vários sectores deste. Os dados recolhidos na imprensa televisiva da época sugerem que existiu uma dinâmica recíproca entre os significados que foram sendo conferidos à televisão, por um lado, e à audiência, por outro, numa negociação entre diferentes aspirações e estratégias, protagonizados por diversos actores sociais. Pode apontar-se, especificamente, uma série de aspectos relevantes nesse processo.

O primeiro aspecto é que o ponto de partida da RTP e o modo oficial de conceber a audiência televisiva foi consonante com a visão salazarista dos meios de comunicação e com a "política do espírito": as massas deviam ser alvo de cultivação por parte de uma televisão didáctica, capaz de educar o gosto, a moral e a ideologia. Nesse sentido, era um projecto antipopular, cuja concepção da audiência era a de um corpo passível de ser progressivamente inoculado com determinadas mensagens, dentro um processo 'vertical' de comunicação. Na fase de arranque da RTP, predominou esta vertente discursiva sobre a TV, que era emanada dos círculos profissionais e interpelava a audiência inicial oferecendo-lhe formas de se imaginar enquanto objecto.

Em segundo lugar, sublinhe-se que não deixaram de se formar duas ideias paralelas de audiência, em competição entre si. A predominante, concebida sob orientação programática do regime, mas também alimentada por meios artísticos e intelectuais que terão visto na televisão uma oportunidade de alargar a sua influência na sociedade portuguesa, era uma audiência a construir à força, à revelia da sua própria vontade. Mas uma segunda concepção foi emergindo, pautada pelos vectores da atenção, do interesse e do gosto, dentro da ideia de que a audiência se ia construindo no interior de dinâmicas recíprocas da emissão e da recepção.

O terceiro aspecto é que esta segunda concepção foi alimentada, também desde cedo, pela introdução de uma ideia igualitária, democratizadora ou niveladora do público televisivo, que passou a acompanhar os discursos sobre a audiência e o papel da televisão, em competição com a concepção oficial e elitista. Mais do que nos jornalistas e críticos de televisão, ou nos produtores e artistas, a ideia de uma televisão que correspondesse aos desejos do público começou por surgir com origem nos próprios espectadores, através do correio do leitor na imprensa televisiva. É aí que se dá a irrupção desse discurso - permitido pelos editores e pelo regime, note-se -, que emerge no seio de um debate entre membros do público e interpela também os responsáveis pela televisão e as elites intelectuais.

Como quarto aspecto note-se que, apesar da lenta formação de uma real audiência e da incipiência técnica dos primeiros anos, o carácter de novidade da televisão proporcionou discursos apaixonados desde o início. Como tema aparentemente 'apolítico', foi possível a emergência de um público que, em certa medida, contrariou temporariamente o clima de quietude e unanimidade e revelou a existência de uma audiência heterogénea, expondo fracturas de gosto cultural e classe social. No seio de uma audiência ainda muito limitada, emergiu, mesmo que transitoriamente, um público que, contraditório e plurifacetado, tomou o novo meio como objecto de direitos e chegou a constituir a televisão como tema com laivos de discussão crítica na praça pública. Aquilo que os espectadores discutem nesse processo vai além do mero gosto de espectadores face aos conteúdos televisivos: discutem as diferenças sociais, os recursos materiais e o papel - realmente político - da televisão enquanto forma de acesso a espectáculos, cultura ou diversão. 
Um último aspecto prende-se com os sinais de que as dinâmicas internas da RTP, em conjugação com o ambiente discursivo que a envolveu a partir do público, terão levado a estação a inflectir a sua visão da audiência. Sem rejeitar o discurso 'cultural' e formativo, a RTP foi diluindo o peso da concepção oficial e passou a perspectivar a audiência como uma massa heterogénea cujos interesses medianos era prioritário contemplar. Mesmo numa situação de monopólio, a estação foi sensível à necessidade de captar telespectadores, não ao ponto de usar as preferências populares para adoptar um discurso populista, mas instalando-se de forma ambivalente no seio da disputa entre as duas concepções da audiência televisiva que se estava a constituir.

A análise da imprensa televisiva em Portugal sugere que no contexto salazarista terá sido a aliança entre o próprio discurso popular - que de alguma maneira se fez ouvir - e a necessidade de a RTP consolidar a audiência nas classes médias e baixas - única forma de servir os objectivos 'formativos' e propagandísticos do regime -, a fazer com que a ideia de audiência nivelada pela mediania fosse abrindo caminho.

\section{Referências}

Bird, E. S. (2008). Seeking the historical audience. In B. Zelizer (ed.), Explorations in Communication and History (pp. 90-106). Londres: Routledge.

Blumer, H. (1969). Symbolic Interaccionism: perspective and method. Berkeley: University of California Press.

Bourdon, J. (2015). Detextualizing: How to write a history of audiences. European Journal of Communication, vol. 30 (1), 7-21.

Brennan, E. (2016). Television in Ireland before Irish Television: Nationalist Rhetoric and International Programming. ECREA Conference, Prague.

Butsch, R. (2000). The Making of American Audiences: From stage to television, 1750-1990. Cambridge: Cambridge University Press.

Cádima, F. R. (1996). Salazar, Caetano e a Televisão Portuguesa. Lisboa: Presença.

Dahlgren, P. (1995). Television and the Public Sphere: Citizenship, democracy and the media. Londres: Sage.

Galhardo, A. (2008). A publicidade ao televisor na imprensa nacional entre 1956 e 1960 nos suportes Jornal de Notícias e Flama. In Actas do 50 Congresso da Associação Portuguesa de Ciências da Comunicação. Braga: Centro de Estudos Comunicação e Sociedade. Disponível online em: http://www.lasics.uminho.pt/ojs/index.php/5sopcom/article/view/81/81

Lozano, J. F. G. (2014). El Encendido Analógico: Los inícios de la televisión en Andalúcia a través de la prensa. Sevilha: Alfar.

Mihelj, S. (2015). Audience history as a history of ideas: Towards a transnational history. European Journal of Communication, vol. 30 (1), 22-35.

Mihelj, S. \& Bourdon, J. (2015). Doing audience history. Questions, sources, methods. European Journal of Communication, vol. 30 (1), 3-6.

Ó, J. R. do (1999). Os Anos de Ferro: O dispositivo cultural durante a "Política do Espírito". Lisboa: Estampa. 
Penati, C. (2013). Il focolare elettronico: Televisione italiana delle origine e culture di visione. Milão: Vita e Pensiero.

Pintado, X. (1967). Níveis e estruturas de salários comparados: os salários portugueses e os europeus. Análise Social, v. 17, 57-89. Disponível online em: http://analisesocial.ics.ul.pt/documentos/1224172603W2bWJ8if0Bg04QN6.pdf

Ribeiro, N. (2005). A Emissora Nacional nos Primeiros Anos do Estado Novo. Porto: Quimera.

Rodrigues, U. T. (1999). Vicissitudes e atropelos no caso da extinção da Sociedade Portuguesa de Escritores. Camões - Revista de Letras e Culturas Lusófonas, 5, 35-38.

Silva, M. L. \& Teves, V. H. (1971). Vamos Falar de Televisão. Lisboa: Verbo.

Sousa, H. e Santos, L. (2005). RTP e Serviço Público: Um percurso de inultrapassável dependência e contradição. In M. Pinto (org.), A Televisão e a Cidadania, Contributos para o Debate sobre o Serviço Público (pp. 61-80). Porto: Campo das Letras.

Spigel, L. (1992). Make Room for TV: Television and the Family Ideal in Postwar America. Chicago: University of Chicago Press.

Torres, E. C. (2011). Televisão e Serviço Público. Lisboa: Fundação Francisco Manuel dos Santos.

Welch, J. (1999). Shaping the box: The cultural construction of American television, 1948-1952. Continuum: Journal of Media and Cultural Studies, 13:1, 97-117. 